\title{
The Determinants Of Corporate Social Responsibility Disclosure: Evidence From China
}

\author{
Jianling Wang, Xi'an Jiaotong University, P. R. China \\ Lin Song, Xi'an Jiaotong University, P. R. China \\ Shujie Yao, University of Nottingham, United Kingdom
}

\begin{abstract}
Employing the content analysis approach, this paper aims to identify the determinants of corporate social responsibility disclosure (CSRD) in China using the annual reports of over 800 A-share listed firms on the Shanghai Stock Exchange. We find that CSRD is positively associated with firm size, media exposure, share ownership concentration and institutional shareholding. Moreover, firms in High-Profile environmentally sensitive industries tend to disclose more corporate social responsibility (CSR) information than those in Low-Profile environmentally sensitive industries, supporting the view that political cost is the primary constraint for Chinese listed firms. Our results provide important insights for academics interested in the CSR issue in emerging economies, for enterprise managers interested in exploiting the annual reports as a strategy to legitimize their corporate social conduct, and for government regulators committed to improving CSR activities and information disclosure.
\end{abstract}

Keywords: Corporate Social Responsibility Disclosure (CSRD); Political Cost; Listed Chinese Firms

\section{INTRODUCTION}

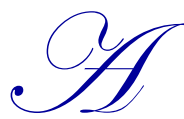

s the world economy becomes more integrated, firms face increasing pressure to disclose their corporate social responsibility (CSR) information over the last few decades (Hooghiemstra, 2000). It is reported that more than half of the Fortune 1,000 firms regularly issue CSR reports (Jo and Kim, 2008). Consequently, corporate social responsibility disclosure (CSRD) has attracted considerable research interests since the 1980s (Ullmann, 1985; Ness and Mirza, 1991; Gray, Kouhy and Lavers, 1995; Blacconiere and Northcut, 1997; Bewley and Li, 2000; Toms, 2002; Patten, 1991, 1992, 2002).

Existing studies suggest that CSRD may bring reporting firms at least two advantages. First, it may enhance corporate reputation through gaining trust and support from various stakeholders (Woodward, Edwards and Birkin, 1996). Second, it is helpful to assess the congruence between the social value implied by corporate activities and social norms (Dowling and Pfeffer, 1975). Information disclosure is closely associated with the social and economic environment, and thus, different social-economic institutions may influence the pattern and level of CSRD.

After more than three decades of fast economic growth, China overtook Japan and became the world's second largest economy in 2010. ${ }^{1}$ However, rapid economic expansion has caused a number of social and environmental problems, including environmental degradation, resource depletion, product quality and safety, social injustice, persistence of poverty and lack of labour protection.

In China, there have been a rising number of firms causing significant damage to the society. For example, in 2008 the San Lu Corporation was found to have produced 'tainted milk powder' which is detrimental to health, or even leading to death of babies. Another example is Foxconn that 13 young workers committed suicides in the first six months of 2010 in this large company making iPods and iPhones for Apple Co.

\footnotetext{
${ }^{1}$ See, Japanese Economy Slips to Third in the World, http://news.sky.com, 16-08-2010. 
These high-profile events evoked serious criticisms throughout China, highlighting the lack of CSR in many Chinese firms. In order to distinguish themselves from these high-profile events and build up good corporate image, an increasing number of Chinese firms start to engage in CSR activities and information disclosure. More importantly, there was a substantial change in 2008 regarding CSR disclosure which may have influenced Chinese listed firms' behaviour and their disclosure practice. CSR information disclosure was voluntary for all companies until the end of 2008 and became mandatory for some listed firms from 2009. In 2008, the Chinese Stock Regulatory Commission (CSRC) made the CSR report an formal requirement for three types of listed firms on the Shanghai Stock Exchange (SSE) (i.e., firms from the finance industry, firms listed on foreign stock exchanges ${ }^{2}$, and firms in the SSE corporate governance composite index group ${ }^{3}$ ), and firms in the Shenzhen 100 composite stock index to disclose along with their annual reports. As CSRC does not provide detailed guidelines for firms, firms can exert some discretion on information to be reported.

This paper extends existing work in three dimensions. First, existing literature mainly focuses on voluntary CSRD (Barakas and Brown 2008), particularly in the western developed countries (Patten, 1991, 1992; Ullmann, 1985; Toms, 2002). China provides a quasi-natural experimental setting to observe the effect of mandatory regulation on CSR disclosure thereby presenting empirical evidence on the firms' response to the government requirements on CSR disclosure. It further enriches literature by investigating the determinants of CSR disclosure in a mandatory context.

Second, this study provides evidence that political cost is a main constraint for Chinese firms to determine whether to disclose CSR Reports and what to be disclosed in annual reports. Existing literature investigates these two theories independently. By using two industry-specific proxies to represent two theories respectively, i.e., environment sensitive industry for political cost theory and consumer proximity industry for legitimacy theory, we investigate the effectiveness of these two theories. Results indicate that political cost theory has priority when Chinese firms determine whether to be disclosed, though both political cost theory and legitimacy theory could be employed to explain the variance of CSR information disclosure between Chinese firms. Our findings provide an important insight for academics interested in CSR development in emerging economies.

Finally, this paper provides an insight into understanding the relationship between CSR disclosure and social publicity. This paper studies the relationship between CSRD and media attraction, and results indicate that a firm's CSRD is positively related to the media attraction. With the fast development of media technology, an increasing number of people are involved in the media agenda and activities (CNNIC, 2013). And hence, our result has significant implications for managers, particularly in the small business.

The remainder of this paper is organized as follows. The second section reviews the theory and empirical evidence of CSRD. A number of hypotheses are also presented. The third section describes data and research methodologies. The fourth section presents empirical results. The final section concludes with some policy recommendations.

\section{LITERATURE REVIEW AND HYPOTHESES DEVELOPMENT}

\subsection{Legitimacy Theory and Political Cost Perspective}

The relationship between a corporation and its environment and the role that CSRD plays in influencing this relationship have become important business issues over the last few decades. A number of studies show that it is difficult for firms investing in CSR activities to maximize their reputation without disclosing information of such activities (Hasseldine, Salama and Toms, 2005; Toms, 2002). Although it seems a little utilitarian and strategic, it is generally accepted that firms engaging in CSR activities usually concern the disclosure of related information because of its contribution to financial performance (Orlitzky, Schmidt and Rynes, 2003; Barnett, 2007) or market value

\footnotetext{
${ }^{2}$ This kind of firms are required to disclose CSR reporting mainly because the international pressure faced by these firms when cross-listing on international stock market exchanges such as Hong Kong Stock Exchange (HKSE) or New York Stock Exchange (NYSE).

${ }^{3}$ The corporate governance composite index group was initiated by the Shanghai Stock Exchange to promote better corporate governance structure. The first index was issued on the first trading day in 2008. Corporations on the SSE can apply to be included. Applications are evaluated for inclusion by a special committee organized by the exchange. Firms on the composite index are reviewed each year. Corporation with bad behaviors would be removed from the index group. In general, firms in this group are often viewed as ones that have better corporate governance practices.
}

1834 Copyright by author(s) $\underline{\text { Creative Commons License CC-BY }}$

2013 The Clute Institute 
(Mackey, Mackey and Barney, 2007). In fact, CSRD is helpful to assess the congruence between the social value implied by CSR activities and the social norms - legitimacy (Dowling and Pfeffer, 1975).

According to the legitimacy theory, CSRD is a response to both public pressure and media attention or social visibility resulting from major social incidents (Patten, 1991, 1992; Walden and Schwartz, 1997; Brown and Deegan, 1998). Legitimacy is fundamental for an organization to survive and exist in the society in the long term, which cannot come from either the making of profit or the mere observing of legal requirements, but the continuing mandate of society at large (Shocker and Sethi, 1974). However, it is almost impossible to maximize firm value and financial performance if a firm is not socially responsible and shares with the public their CSR information (Pava and Krausz, 1996). For example, Sanlu Corporation went bankruptcy for producing 'tainted milk powder' in 2008, and Foxxcon had to move its factory to another province because of the continuous worker suicide event in 2010.

CSRD is reactive to environmental factors and disclosures legitimize actions (Guthrie and Parker, 1989). Deegan, Rankin and Voght (2000) argue that the increase in social disclosures represents a strategy to alter public perception about the legitimacy of an organization, and then achieve the continuing mandate of society. CSRD is a critical way for firms to communicate with society, to convince the public that they are meeting their social expectations (Branco and Rodrigues 2008). Consequently, CSRD can be considered as a signal of building up legitimacy thereby improving firms' social and environmental conducts and social reputation (Neu, Warsame and Pedwell, 1998; O'Donovan 2000; Guthrie and Parker 1989). Patten (1992) suggests that social information in annual reports can influence public policies, directly by addressing public and/or legislative concerns, or indirectly by projecting an image of the company's social awareness. It is argued that the greater the likelihood of adverse shifts in public policy, the greater the need to influence the process through social disclosure.

On the other hand, researchers developed a political cost hypothesis to argue that firms employ social responsibility activities to reduce the risk of governmental intrusions, such as regulation, that may adversely affect firm value (Watts and Zimmerman, 1978). Government controls critical resources, with an important power to affect wealth transfers between different groups, while the business enterprises are vulnerable to these wealth redistributions. And hence, corporations employ a lot of devices, such as corporate social responsibility disclosure, to counter the potential government intrusions (Watts and Zimmerman, 1978).

In China, CSR information disclosure has been voluntary for all firms for years. The requirement of Chinese Stock Regulatory Commission (CSRC) in 2008 changed CSR information disclosure practice drastically, mandatory for some firms and voluntary for others. In the field of CSR research, however, legitimacy theory is rooted in a voluntary context, while political cost perspective is associated with government regulation. Based on these two aspects, we develop hypotheses to investigate the factors that influence CSR information disclosure quantity in a more plural society.

\subsection{Hypothesis Development}

\subsubsection{Industry}

Industry classification is a commonly accepted factor to distinguish CSRD among different firms in existing studies. However, some industries face more rigorous scrutiny, while others are under more social visibility and public pressure. Numerous researchers (e.g., Bowman and Haire, 1975; Cowen, Ferreri and Parker, 1987; Ness and Mirza, 1991; Gao, 2009) note that the extent to which public pressure firms face regarding social issues varies across industries. Firms with more environmental impact are found to disclose more environmental information than others due to the higher public pressure (Patten, 1991; Adams, Hill and Roberts, 1998). For example, the extractive and chemical industries tend to produce more pollution than other industries. Hence, they are subject to more public pressure regarding their environmental impact and product safety (Dierkes and Preston, 1977). More importantly, with the improvement of environment protection policies, firms in high-profile environment sensitive industries might face much higher political costs for non-compliance with the rules than others. Accordingly, we posit the following hypothesis:

H1a: Firms in environmentally sensitive industries tend to disclose more CSR information than others, especially CSR information related to environment responsibility. 
In addition, from a consumer visibility perspective, firms producing goods which are widely consumed tend to generate more social visibility (Branco and Rodrigues, 2008). After the Wenchuan Earthquake on 12 May 2008, for example, many firms donated money to the earthquake relief efforts. The JDB Associates, a private Chinese company producing soft drinks, became well-known almost overnight due to its 100 million RMB donation ${ }^{4}$. The soft drink 'Wang Laoji', a main product of JDB Co., received rocketing demand and tremendous reaction from customers after the donation. The company name was also quickly known all over the country. And hence, we posit the following hypothesis:

H1b: Firms in consumer proximity industries are more likely to disclose CSR information than others, especially CSR information related to consumer responsibility.

\subsubsection{Firm Size}

A number of studies indicate that large firms are subject to more social and political pressure than small firms. Trotman and Bradley (1981) find that company size appears a significant explanatory variable in their studies of social responsibility disclosure. Cowen, Ferreri and Parker (1987) argue that "the larger firms tend to receive more attention from the general public and, therefore, to be under greater public pressure to exhibit social responsibility." Larger organizations such as BP and Shell under intense public scrutiny due to their controversial activities push and proselytize the CSR agenda, and then win CSR disclosure award. Ahmed and Courtis (1999) also suggest that size is one of the most important predictors of disclosure level in corporate annual reports. Because larger firms are assumed to face greater pressures than smaller firms, the former will increase their disclosures more than the latter to establish a good social image as part of their business strategy.

In light of the political cost, larger firms, compared with the smaller firms, usually assume higher political costs because large firms suffer more rigorous scrutiny from the regulatory agencies. Watts and Zimmerman (1978) argue that larger firms falling into the mandatory requirements are more politically sensitive and visible in the stakeholders' eye than smaller ones. Managers of larger firms may disclose social activities in an independent CSR report or annual reports as part of a strategy to enhance or change the perception of stakeholders or manage, or to reduce political costs by satisfying the mandatory requirements. Accordingly, we posit the following hypothesis.

H2: Corporate social responsibility disclosure is positively associated with firm size.

\subsubsection{Media Exposure}

Individual firms' media exposure, which is generally employed as a proxy for social visibility, is likely to be associated with more CSRD (Bansal, 2005; Brammer and Pavelin, 2008; Branco and Rodrigues, 2008; Reverte, 2009). Bansal (2005) suggests that more media coverage raises firms' visibility, making them the object of further public attention and scrutiny and inviting further public attention and scrutiny (Branco and Rodrigues 2008).

In addition, media plays an important role in affecting stakeholders' decision because it is the main source of CSR information (Simon 1992). In China, listed firms are required to issue annual reports in three designated national newspapers: China Securities Journal, Securities Times, and Shanghai Securities Gazette. Listed firms can disclose annual reports on any or all of these three newspapers. By publishing annual reports in more than one media outlet, firms aim to attract more public attention to their CSR activities and legitimize the conduct. Consequently, we posit the following hypothesis:

H3: Corporate social responsibility disclosure is positively associated with the media exposure.

\section{RESEARCH DESIGN AND METHODOLOGIES}

\subsection{Data and Sample}

The sample used in this study comprises all A-share firms listed on the Shanghai Stock Exchange (SSE). Firms listed on the Shenzhen Stock Exchange (SZSE) are not used in this study because regulatory rules governing

\footnotetext{
${ }^{4}$ It was reported that this was the first 100 million RMB philanthropic giving after the Wenchuan Earthquake. 1836 Copyright by author(s) $\underline{\text { Creative Commons License CC-BY } 2013 \text { The Clute Institute }}$
} 
both stock exchanges are not comparable. Furthermore, to achieve meaningful and consistent results, firms are included in the sample if they meet following criteria: (1) listed on SSE before the end of 2009; (2) annual reports for 2008 and/or 2009 available; (3) financial data available from China Stock Market and Accounting Research Database (CSMAR) ${ }^{5}$. Applying the above-mentioned criteria, 851 and 856 firms are selected in this study for 2008 and 2009 respectively ${ }^{6}$. CSR information item and media exposure data are manually collected by two Master students. All the data related to the financial statements and corporate governance used in this paper are from CSMAR database. Summary statistics are reported in Table 1.

Table 1: Summary Statistics of the Sample Firms

\begin{tabular}{lcc}
\hline \multicolumn{1}{c}{ Industry Distribution } & $\mathbf{2 0 0 8}$ & $\mathbf{2 0 0 9}$ \\
$\mathbf{N}(\boldsymbol{\%})$ & $\mathbf{N}(\mathbf{\%})$ & $20(2.34)$ \\
\hline Agriculture, Forestry, Fishing \& Hunting & $21(2.47)$ & $28(3.27)$ \\
Mining & $27(3.17)$ & $438(51.17)$ \\
Manufacturing & $439(51.59)$ & $42(4.91)$ \\
Electricity, Gas \& Water Supply & $39(4.58)$ & $22(2.57)$ \\
Construction & $23(2.70)$ & $48(5.61)$ \\
Transport \& Storage & $49(5.76)$ & $51(5.96)$ \\
Information \& Technology & $50(5.88)$ & $59(6.89)$ \\
Wholesale \& Retail Trade & $61(7.17)$ & $23(2.69)$ \\
Finance \& Insurance & $20(2.35)$ & $49(5.72)$ \\
Real Estate & $44(5.17)$ & $23(2.69)$ \\
Social Services & $22(2.59)$ & $8(0.93)$ \\
Media \& Culture & $9(1.06)$ & $45(5.26)$ \\
Conglomerate & $47(5.52)$ & \\
\hline Not Num
\end{tabular}

Notes: Numbers in brackets are proportion of the total number of firms.

The sample firms are grouped according to the Industry Classification issued by the China Security Regulatory Commission (CSRC) in $2001^{7}$. Manufacturing sector provides the largest population of CSR information items, accounting for more than half of all sample firms. The Wholesale \& Retail Trade industry sector follows. The Media and Culture industry provides the fewest of all sectors. On average, firm size, measured by total assets at the fiscal year end, increased from 53,311 million RMB in 2008 to 66,430 million RMB in 2009. Amongst the sample firms, Industrial and Commercial Bank of China Limited (ICBC) was the largest in both years, with a total asset of 9,757 billion RMB in 2008 and 11,875 billion RMB in 2009, respectively.

\subsection{Measurement}

\subsubsection{Dependent Variables}

The definition of CSR differs between firms, but in general, CSR covers a multi-dimensional perspective relating to the environment, society and business community (Tsoi, 2010). The term "responsibility" also extends from the pure financial aspects for shareholders to environmental, social and community issues. Moreover, Different kinds of firms may have different activities towards CSRD. In this paper, CSRD is embedded in annual reports which are obtained from A-share firms listed on SSE. An information item is considered as CSRD if it is related to one or more of the following stakeholders: shareholders, employees, consumers and products, environment, community and other interests (i.e., government or suppliers responsibility). In total 20 specific items are covered in this study. The responsibility item list is based on the set of Guideline of Corporate Social Responsibility for Listed Firms issued by Shenzhen Stock Exchange (SZSE) and some international standards such as ISO 26000 and GRI 3.1. ${ }^{8}$ In addition,

\footnotetext{
${ }^{5}$ China Stock Market and Accounting Research Database (CSMAR), which is a professional database about Chinese stock market provided by GTA Co. in Shenzhen, http://www.gtadata.com/about/about.aspx.

${ }^{6}$ Both 2008 and 2009 refer to the firm's fiscal year. CSRC regulation on CSR information disclosure took effect in 2009, when firms publish their annual reports of the fiscal year 2008.

${ }^{7}$ Industry classification is based on the 'Industry Classification Guideline of Listed Firms' issued by CSRC in 2001, the industry classification of each company are extracted from CSMAR data.

${ }^{8}$ In May 2008, Shanghai Stock Exchange (SSE) issued How to Strengthen CSR in Listed Firms and Guideline of Environment Information Disclosure of Listed Firms in SSE, and there is no guideline related to CSR on SSE.
} 
CSRD in this paper is classified into 6 categories relating to different stakeholders, including shareholders, employees, customer services, environment, community and others. Table 2 summarizes the CSR items of Chinese listed firms.

Table 2: Number of Chinese Listed Firms Reporting CSR Information

\begin{tabular}{|c|c|c|c|}
\hline CSR Items & $\begin{array}{c}2008 \\
\mathbf{N}(\%) \\
\end{array}$ & $\begin{array}{c}2009 \\
\mathbf{N}(\%) \\
\end{array}$ & Change \% \\
\hline \multicolumn{4}{|l|}{ Shareholder Responsibility } \\
\hline Corporate Governance & $848(99.65)$ & $856(100.00)$ & 0.35 \\
\hline Obligation to Disclose & $656(77.09)$ & $703(82.13)$ & 5.04 \\
\hline Bonus Information & $194(22.80)$ & $172(20.09)$ & -2.70 \\
\hline \multicolumn{4}{|l|}{ Employee Responsibility } \\
\hline Fair Employment & $165(19.39)$ & $196(22.90)$ & 3.51 \\
\hline Health \& Safety & $226(26.56)$ & $212(24.77)$ & -1.79 \\
\hline Training and Education & $244(28.67)$ & $240(28.04)$ & -0.63 \\
\hline Professional Development & $109(12.81)$ & $110(12.85)$ & 0.04 \\
\hline Employee's Welfare & $193(22.68)$ & $238(27.80)$ & 5.12 \\
\hline \multicolumn{4}{|l|}{ Consumers and Products } \\
\hline Product Quality \& Safety & $199(23.38)$ & $199(23.25)$ & -0.14 \\
\hline Customer Services & $166(19.51)$ & $171(19.98)$ & 0.47 \\
\hline Consumer Rights & 85 (9.99) & $60(7.01)$ & -2.98 \\
\hline \multicolumn{4}{|l|}{ Environment/Energy Responsibility } \\
\hline Pollution Control & $168(19.74)$ & $141(16.47)$ & -3.27 \\
\hline Environmental Conservation & $144(16.29)$ & $75(8.76)$ & -8.16 \\
\hline Conserving Natural Resources & $72(8.46)$ & $53(6.19)$ & -2.27 \\
\hline Energy Saving/Emission Reduction & $303(35.61)$ & $319(37.27)$ & 1.66 \\
\hline \multicolumn{4}{|l|}{ Community Responsibility } \\
\hline Philanthropic Giving & $247(29.02)$ & $210(24.53)$ & -4.49 \\
\hline Public Welfare Undertaking & $241(28.32)$ & $248(28.97)$ & 0.65 \\
\hline Community Involvement & $119(13.98)$ & $82(9.58)$ & -4.40 \\
\hline \multicolumn{4}{|l|}{ Other Responsibility } \\
\hline Government Responsibility & $110(12.93)$ & $138(16.12)$ & 3.20 \\
\hline Suppliers' Responsibility & $174(20.45)$ & $185(21.61)$ & 1.17 \\
\hline Total of Disclosure Items & 4665 & 4608 & \\
\hline
\end{tabular}

Notes: Numbers in brackets refer to proportion of the number of firms disclosing a certain item to the total number of firms (851 for 2008, 856 for 2009).

According to Table 2, there are 4665 pieces of CSR information disclosed in the annual reports of listed firms in 2008 and 4608 in 2009, respectively. The number of firms disclosing "employee welfare" item in employee responsibility section increases the highest, with a positive increase of $5.12 \%$, while the number of firms disclosing the item "environmental conservation" in the environment/ energy responsibility section decreases the most, with a negative percentage of 8.16. With regard to the absolute value, we note that here were 144 pieces of information in 2008 and only 75 in 2009, respectively. And hence, CSR disclosure in 2009 is less than that in 2008 generally.

\subsubsection{Independent Variables}

A binary codification is used to measure the environmental sensitivity proxy. High-profile environmental sensitive industries are considered to be those with more risk of being criticized in CSR matters because of their operations that inherently harm the natural environment. Based on existing literature (Patten, 1991; Adams, Hill and Roberts, 1998), the following "more sensitive" sectors are identified: Forestry, Mining, Paper, Oil and gas generating, Chemicals, Steel and other metals, Electricity, gas and water supply. All other industries are considered low-profile environment sensitive industries. A dummy variable, ENVI, is used to represent the environmental sensitivity: taking the value of 1 if a company is from a high-profile environmental industry and 0 otherwise.

Depending on the closeness to consumer and community, ${ }^{9}$ firms are classified as two types: High-Profile firms with products close to community and final consumers and Low-Profile firms with products not so close to

\footnotetext{
${ }^{9}$ Consumer and community proximity is simplified as consumer proximity for reading convenience in the following parts of this study.
}

1838 
community and consumers. According to Branco and Rodrigues (2008), the following industries are assumed to have high consumer proximity: Food manufacturing, Textiles, Household goods, Telecommunication Services, Food and Drug retailers, and Finance. A dummy variable, CONS, takes the value of 1 if a company belongs to a High-Profile consumer proximity industry and 0 otherwise.

Firm size (SIZE) is measured by the natural logarithm of total assets. Media exposure (MED) is measured by the number of newspapers where firms publish their annual reports. MED takes the value of 2 if annual reports are published in all the three officially designated newspapers and at least one other newspaper. It takes the value of 1 if annual reports are published in all the three designated newspapers but not in any other newspapers. It takes the value of 0 if annual reports are published only in one or two of the three designated newspapers.

\subsubsection{Control Variables}

We control for firm age (AGE), ownership concentration (CONC), institutional shareholding percentage (INS) and disclosure year (YEAR). Specifically, firm age is represented by the number of years from when firms are listed on the stock exchange to the reporting year. Ownership concentration is measured by the ratio of shares held by the largest shareholder as a proportion of the total number of shares listed on the stock exchange (for example, Ghazali 2007). Institutional shareholding percentage is measured by the ratio of shares held by institutional investors as a proportion of all the shares listed on the stock market (Roberts 1992; Ullmann 1985). Year is a dummy variable that is used to control the possible effect of time on the level of CSRD.

\subsection{Model}

The key methodology of this paper is to develop a multivariate regression model to test our hypotheses and identify the key determinants of CRSD among Chinese listed firms in 2008 and 2009.

Seven different specifications are constructed with same explanatory variables but different dependent variables. Dependent variables include total CSRD in the annual reports (CSRDT), shareholder responsibility (CSRDSH), employee responsibility (CSRDEM), consumer responsibility (CSRDCS), environmental responsibility (CSRDEN), community responsibility (CSDRCM), and other responsibility (CSRDOT).

Equation (1) presents the common format of all different models on the right hand side. The only difference between various models is the dependent variable on the left hand side.

$$
\begin{aligned}
\operatorname{CSRD}_{i t}= & \alpha_{0}+\alpha_{1} \mathrm{ENVI}_{i t}+\alpha_{2} \operatorname{CONS}_{i t}+\alpha_{3} \operatorname{SIZE}_{i t}+\alpha_{4} M E D_{i t}+\alpha_{5} A G E_{i t} \\
& +\alpha_{6} \operatorname{CONC}_{i t}+\alpha_{7} I_{i N}+\alpha_{8} Y_{i t} R_{i t}+\varepsilon
\end{aligned}
$$

where for company $i$ : $C S R D_{i t}$ refers to the CSRD index in year t (i.e., CSRDT; CSRDSH; CSRDEM; CSRDCS; CSRDEN; CSRDCM and CSRDOT, respectively); ENVI, environmental sensitivity; CONS, consumer proximity; SIZE, company size; $M E D$, media exposure; $A G E$, firm age; CONC, ownership concentration; INS, institutional shareholding; YEAR, time variable; $\varepsilon$, error term.

\section{EMPIRICAL RESULTS}

\subsection{Descriptive Statistics}

The content analysis approach is employed to measure CSR disclosure level. The procedure is as follows. First, check against the given responsibility item list. Second, a score is assigned depending on whether an item is disclosed and the extent to which it is disclosed. A score of 2 is assigned if an item is disclosed in great detail. A score of 1 is assigned if an item is disclosed qualitatively without detailed explanation. If no related information is disclosed, the score is 0 . For example, if a company discloses a detailed plan on pollution, estimated expenditure, or main development related to environmental protection, a score of 2 will be given. Third, for each company, scores are then added up to quantify the level of CSRD for each of the aspects and for all the aspects as a whole. Finally, to avoid the potential effects of the number of items evaluated for different responsibility sections, an index is given by dividing all the above-mentioned scores assigned to that company by the maximum possible scores for each given firm. In order to 
keep the analysis process of CSRD index consistent and valid, a Master student is responsible for the whole process, and another Master student checked and confirmed all work independently. One author extracted and checked some sample data. The whole process takes about six months.

Table 3 presents the descriptive statistics of the index for each category of CSRD and the total CSRD index. The values of the three categories of CSRD (CSRDSH, CSRDEM and CSRDOT) increased slightly from 2008 to 2009. The values of the other three categories (CSRDCS, CSRDEN and CSRDCM) declined over the same period. The mean of CSRDT was only 0.27 in 2008 and 2009. This implies that the level of CSRD by Chinese listed firms was quite low.

Table 3: Descriptive Statistics of CSRD Index in 2008 and 2009

\begin{tabular}{lcccccccc}
\hline \multirow{2}{*}{ Variables } & \multicolumn{3}{c}{$\mathbf{2 0 0 8}$} & \multicolumn{3}{c}{$\mathbf{2 0 0 9}$} \\
\cline { 2 - 9 } & Mean & S.D. & Minimum & Maximum & Mean & S.D. & Minimum & Maximum \\
\hline CSRDSH & 0.664 & 0.214 & 0.000 & 1.000 & 0.673 & 0.199 & 0.167 & 1.000 \\
CSRDEM & 0.217 & 0.332 & 0.000 & 1.000 & 0.230 & 0.347 & 0.000 & 1.000 \\
CSRDCS & 0.170 & 0.292 & 0.000 & 1.000 & 0.163 & 0.269 & 0.000 & 1.000 \\
CSRDEN & 0.196 & 0.289 & 0.000 & 1.000 & 0.169 & 0.246 & 0.000 & 1.000 \\
CSRDCM & 0.240 & 0.374 & 0.000 & 1.000 & 0.200 & 0.328 & 0.000 & 1.000 \\
CSRDOT & 0.160 & 0.303 & 0.000 & 1.000 & 0.182 & 0.330 & 0.000 & 1.000 \\
CSRDT & 0.270 & 0.262 & 0.050 & 0.950 & 0.265 & 0.250 & 0.025 & 0.900 \\
\hline
\end{tabular}

There are four items relating to environment responsibility: pollution control, environmental conservation, natural resource conservation, and energy-saving/emission reduction. As discussed in the previous section, firms are divided into two types: high-profile environmentally sensitive firms and low-profile environmentally sensitive firms. Figure 1 compares the levels of CSRD relating to the four environmental information items between the two types of firms. It reveals that high-profile environmentally sensitive firms tend to disclose more than the low-profile environmentally sensitive firms. For example, $46 \%$ of high-profile environmentally sensitive firms disclosed energy saving and emission reduction information in 2009, while this percentage is only $36 \%$ in the low-profile environmentally sensitive firm group.

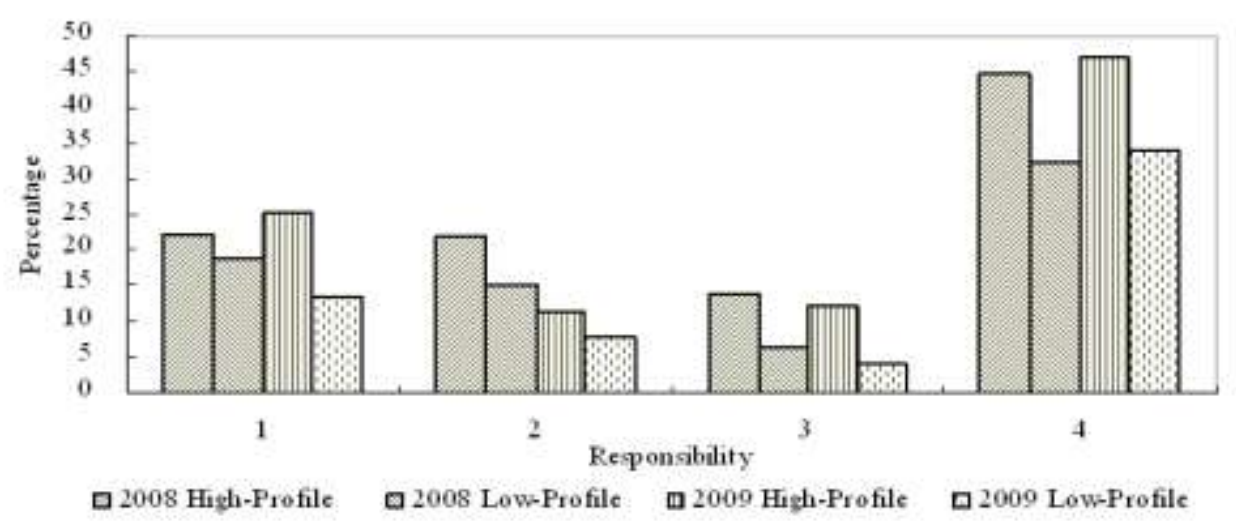

Figure 1: Information Disclosure by High/Low Environmentally Sensitive Industries

Notes: 1 = pollution control; 2 = environmental conservation; 3 = natural resource conservation and 4 = energy-saving/emission reduction. High-Profile $=$ High-Profile environmentally sensitive industries; Low-Profile = Low-Profile environmentally sensitive industries.

Six responsibility items are employed to represent consumer and community responsibilities, namely production quality and safety, costumer services; consumer rights, philanthropic giving, public welfare undertaking, and community involvement.

Figure 2 compares the different levels of information disclosure by these two types of firms for all the six items. Apart from the disclosure of information on product quality and safety, High-Profile firms tend to disclose more information of all the other items than Low-Profile firms. For most items, however, the level of information disclosed declined from 2008 to 2009. 


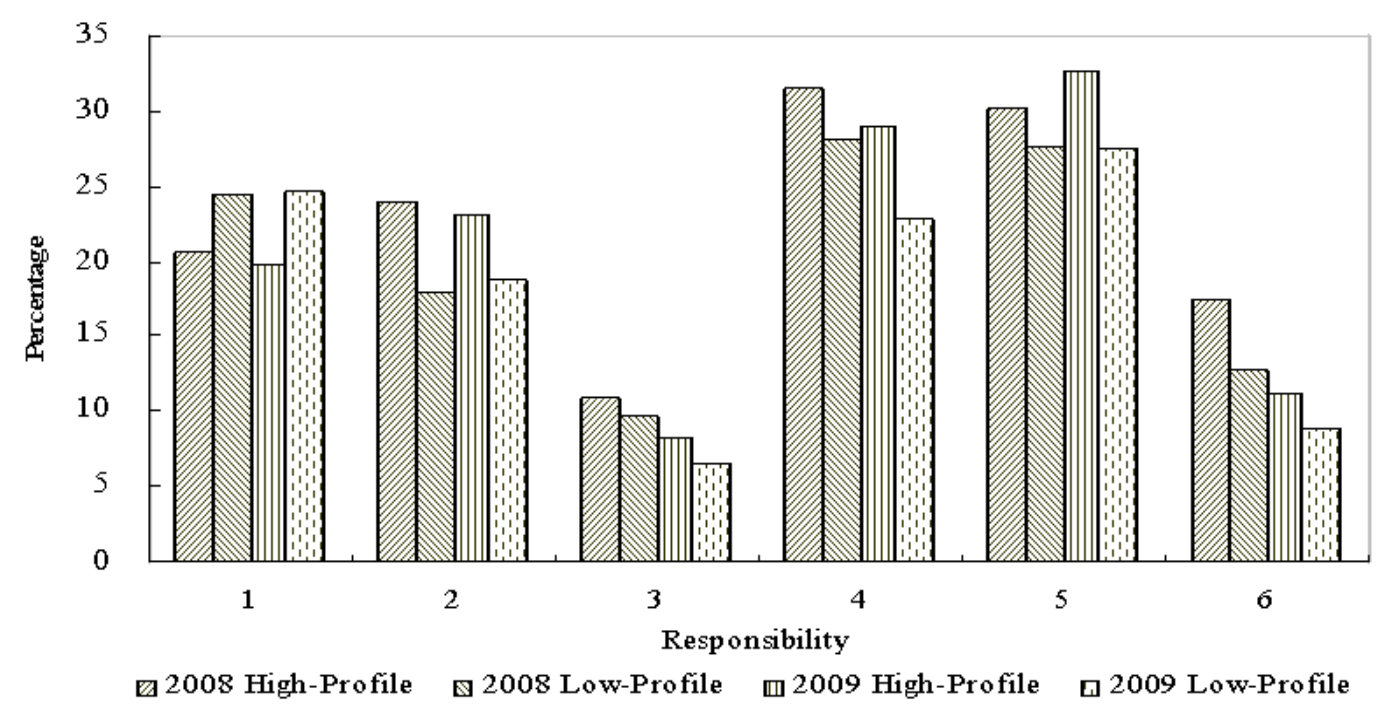

Figure 2: Information Disclosure by High/Low Consumer Proximity Industries Notes: 1 = Product quality/safety; 2 = customer services; 3 = consumer rights; 4 = philanthropic giving; $5=$ public welfare undertaking $6=$ community involvement. High-Profile $=$ High-Profile consumer proximity; Low-Profile $=$ Low-Profile consumer proximity.

According to the requirement set by SSE and CSRC in 2008, three kinds of firms (i.e., firms from the finance industry, firms listed on foreign stock exchanges, and firms in the SSE corporate governance composite index group) are required to disclose their CSR reports along with their annual reports. Table 4 presents the results of CSR reports disclosed by listed firms.

Table 4: CSR Reports Disclosed by Listed Firms on SSE

\begin{tabular}{lcccc}
\hline \multicolumn{1}{c}{ Firms } & \multicolumn{2}{c}{$\mathbf{2 0 0 8}$} & \multicolumn{2}{c}{} \\
\cline { 2 - 5 } & $\mathbf{N}$ & $\mathbf{\%}$ & $\mathbf{N}$ & $\mathbf{\%}$ \\
\hline Finance/Insurance & 19 & 95.0 & 14 & 60.9 \\
Listed on foreign exchanges & 48 & 96.0 & 35 & 66.0 \\
SSE governance board & 221 & 95.7 & 156 & 65.3 \\
Mandatory disclosure firms & 247 & 95.7 & 169 & 63.8 \\
Total sample & 282 & 33.1 & 283 & 33.1 \\
\hline
\end{tabular}

Notes: $\mathrm{N}=$ number of firms publishing CSR reports. $\%=$ a proportion of the number of firms publishing CSR reports to the total number of firms within the corresponding category on SSE.

The results in Table 4 indicate that 282 firms published their CSR reports in 2008 and 283 in 2009 respectively, accounting for one third of sample firms in both years. For mandatory CSR disclosers, $96 \%$ of the firms publish their CSR reports in 2008, but this proportion declined to only $64 \%$ in 2009 . In contrast, the number of firms which voluntarily disclose CSR reports rose significantly, from 35 in 2008 to 114 in 2009.

Figure 3 shows the distribution of listed firms which publish CSR reports voluntarily by industry. Three industries published their CSR reports in 2009 for the first time, including agriculture, forestry, fishery and hunting; construction; and social services. Manufacturing was the dominant industry disclosing CSR reports. The number of firms disclosing CSR information in the Information and Technology industry increased dramatically from only 1 in 2008 to 10 in 2009. This may be due to the rising public pressure on firms of this industry to publish their CSR information because the industry has become ever more important in the Chinese economy. 


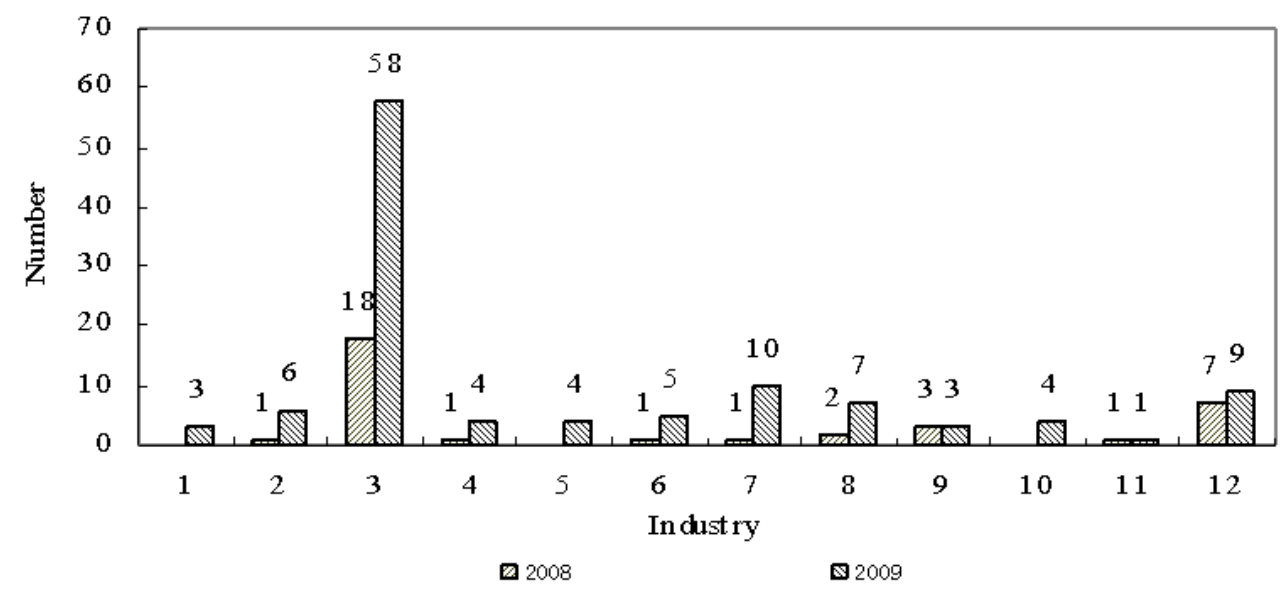

Figure 3: Firms Voluntarily Published CSR Reports by Industry

Notes: 1 = agriculture, forestry, fishing $\&$ hunting; 2 = mining; 3 = manufacturing; 4 = electricity, gas \& water supply; $5=$ construction; $6=$ transport $\&$ storage; $7=$ information $\&$ technology; $8=$ wholesale $\&$ retails $; 9=$ real estate $; 10=$ social services $; 11=$ media $\&$ culture $; 12=$ conglomerate.

\subsection{Multivariate Regression Results}

Before regression analysis, a series of diagnostic tests, such as multicollinearity test, have been carried out to ensure the validity and reliability of regression results. Multicollinearity is tested based on the correlation matrix incorporating all the independent variables as well as computing the variance inflation factor (VIF). Table 5 reports the correlation matrix which indicates that the highest correlation coefficient is 0.32 . The highest value of VIF is far less than $2{ }^{10}$ All results suggest that multicollinearity is unlikely to be a problem.

Table 5: Correlation Coefficients between Explanatory Variables

\begin{tabular}{|c|c|c|c|c|c|c|c|c|}
\hline Variables & ENVI & CONS & SIZE & MED & AGE & CONC & INS & YEAR \\
\hline ENVI & 1.000 & & & & & & & \\
\hline CONS & $\begin{array}{c}-0.120^{* * * *} \\
(0.000)\end{array}$ & 1.000 & & & & & & \\
\hline SIZE & $\begin{array}{c}0.135^{* * * * *} \\
(0.000)\end{array}$ & $\begin{array}{c}0.080^{* * * *} \\
(0.001)\end{array}$ & 1.000 & & & & & \\
\hline MED & $\begin{array}{c}-0.004 \\
(0.857)\end{array}$ & $\begin{array}{c}0.030 \\
(0.213)\end{array}$ & $\begin{array}{c}0.257^{* * *} \\
(0.000)\end{array}$ & 1.000 & & & & \\
\hline AGE & $\begin{array}{l}-0.148 \\
(0.000)\end{array}$ & $\begin{array}{c}0.028 \\
(0.247)\end{array}$ & $\begin{array}{c}-0.264^{* * * *} \\
(0.000)\end{array}$ & $\begin{array}{c}-0.189^{* * * *} \\
(0.000)\end{array}$ & 1.000 & & & \\
\hline CONC & $\begin{array}{c}0.163^{* * * * *} \\
(0.000)\end{array}$ & $\begin{array}{c}-0.153^{* * *} \\
(0.000)\end{array}$ & $\begin{array}{c}0.320^{* * * *} \\
(0.000)\end{array}$ & $\begin{array}{c}0.009 \\
(0.695)\end{array}$ & $\begin{array}{c}-0.170^{* * * *} \\
(0.000)\end{array}$ & 1.000 & & \\
\hline INS & $\begin{array}{l}-0.019 \\
(0.435)\end{array}$ & $\begin{array}{c}-0.071 \\
(0.003)\end{array}$ & $\begin{array}{l}0.207^{* * *} \\
(0.000)\end{array}$ & $\begin{array}{l}0.084^{* * * *} \\
(0.001)\end{array}$ & $\begin{array}{c}-0.073^{\text {**** }} \\
(0.003)\end{array}$ & $\begin{array}{c}-0.034 \\
(0.162)\end{array}$ & 1.000 & \\
\hline YEAR & $\begin{array}{c}0.023 \\
(0.353)\end{array}$ & $\begin{array}{c}0.009 \\
(0.722)\end{array}$ & $\begin{array}{l}0.046^{*} \\
(0.057)\end{array}$ & $\begin{array}{c}0.028 \\
(0.255)\end{array}$ & $\begin{array}{c}0.110^{* * * *} \\
(0.000)\end{array}$ & $\begin{array}{l}-0.007 \\
(0.778)\end{array}$ & $\begin{array}{l}-0.017 \\
(0.480)\end{array}$ & 1.000 \\
\hline
\end{tabular}

Notes: (1) ENVI = environmentally sensitivity, CONS = consumer proximity, SIZE = firm size, MED = media exposure, AGE = firm age, $\mathrm{CONC}=$ ownership concentration, INS $=$ institutional shareholding, YEAR $=$ time dummy. (2) *, **, *** Significant at $10 \%, 5 \%, 1 \%$ respectively (2-tailed).

Table 6 reports the multivariate regression results. Three interesting results are evident. First, firm size is positively associated with the level of CSRD in all regressions, supporting the hypothesis H2. Second, the extent of media exposure is positively related with the level of CSRD, supporting the hypothesis H3. Third, we find environment sensitive industries and consumer proximity industries respond to the stringent regulation and public visibility differently.

${ }^{10}$ VIF results are not included in this table due to space limitations (results available upon request) 
Table 6: Regression Results of Models using Different CSRD Indicators as Dependent Variables

\begin{tabular}{|c|c|c|c|c|c|c|c|c|c|c|c|}
\hline $\begin{array}{c}\text { Dependent } \\
\text { Variables }\end{array}$ & Intercept & ENVI & CONS & SIZE & MED & AGE & CONC & INS & YEAR & Adj. $\mathbf{R}^{2}$ & D-W \\
\hline CSRDSH & $\begin{array}{c}0.255^{* * * *} \\
(0.001)\end{array}$ & $\begin{array}{l}-0.015 \\
(0.541)\end{array}$ & $\begin{array}{l}-0.392 \\
(0.695)\end{array}$ & $\begin{array}{c}0.155^{* * * *} \\
(0.000)\end{array}$ & $\begin{array}{l}0.043^{*} \\
(0.078)\end{array}$ & $\begin{array}{c}-0.104^{* * *} \\
(0.000)\end{array}$ & $\begin{array}{l}0.042^{*} \\
(0.097)\end{array}$ & $\begin{array}{l}0.095^{* * * *} \\
(0.000)\end{array}$ & $\begin{array}{c}0.027 \\
(0.251)\end{array}$ & 0.070 & 1.887 \\
\hline CSRDEM & $\begin{array}{c}-1.331^{* * * *} \\
(0.000)\end{array}$ & $\begin{array}{c}-0.050^{* * *} \\
(0.024)\end{array}$ & $\begin{array}{l}-0.009 \\
(0.695)\end{array}$ & $\begin{array}{c}0.348^{* * * *} \\
(0.000)\end{array}$ & $\begin{array}{l}0.054^{* * *} \\
(0.018)\end{array}$ & $\begin{array}{c}-0.113^{* * * *} \\
(0.000)\end{array}$ & $\begin{array}{l}0.061^{* *} \\
(0.011)\end{array}$ & $\begin{array}{l}0.082^{* * * *} \\
(0.000)\end{array}$ & $\begin{array}{c}0.017 \\
(0.439)\end{array}$ & 0.201 & 1.928 \\
\hline CSRDCS & $\begin{array}{c}-0.961^{* * * *} \\
(0.000)\end{array}$ & $\begin{array}{c}-0.057^{* *} \\
(0.013)\end{array}$ & $\begin{array}{l}-0.018 \\
(0.422)\end{array}$ & $\begin{array}{c}0.304^{* * * *} \\
(0.000)\end{array}$ & $\begin{array}{l}0.059^{* *} \\
(0.012)\end{array}$ & $\begin{array}{c}-0.073^{* * *} \\
(0.002)\end{array}$ & $\begin{array}{c}0.031 \\
(0.209)\end{array}$ & $\begin{array}{l}0.126^{* * * *} \\
(0.000)\end{array}$ & $\begin{array}{l}-0.019 \\
(0.385)\end{array}$ & 0.158 & 1.838 \\
\hline CSRDEN & $\begin{array}{c}-1.107^{* * * *} \\
(0.000)\end{array}$ & $\begin{array}{c}0.064^{* * *} \\
(0.004)\end{array}$ & $\begin{array}{l}-0.010 \\
(0.654)\end{array}$ & $\begin{array}{c}0.355^{* * * *} \\
(0.000)\end{array}$ & $\begin{array}{c}0.058^{* * * *} \\
(0.009)\end{array}$ & $\begin{array}{c}-0.081^{* * * *} \\
(0.000)\end{array}$ & $\begin{array}{c}0.071^{\text {**** }} \\
(0.002)\end{array}$ & $\begin{array}{c}0.094^{* * * *} \\
(0.000)\end{array}$ & $\begin{array}{c}-0.058^{* * * *} \\
(0.007)\end{array}$ & 0.223 & 1.883 \\
\hline CSRDCM & $\begin{array}{c}-1.649^{* * * *} \\
(0.000)\end{array}$ & $\begin{array}{c}-0.044^{* * *} \\
(0.043)\end{array}$ & $\begin{array}{c}0.014 \\
(0.532)\end{array}$ & $\begin{array}{c}0.403^{\text {***** }} \\
(0.000)\end{array}$ & $\begin{array}{l}0.060^{* * * *} \\
(0.007)\end{array}$ & $\begin{array}{c}-0.081^{* * * *} \\
(0.000)\end{array}$ & $\begin{array}{c}0.030 \\
(0.188)\end{array}$ & $\begin{array}{l}0.089^{* * * *} \\
(0.000)\end{array}$ & $\begin{array}{c}-0.056^{* * * *} \\
(0.009)\end{array}$ & 0.235 & 1.872 \\
\hline CSRDOT & $\begin{array}{c}0.939^{* * * *} \\
(0.000)\end{array}$ & $\begin{array}{l}-0.023 \\
(0.321)\end{array}$ & $\begin{array}{l}-0.008 \\
(0.734)\end{array}$ & $\begin{array}{c}0.252^{* * * *} \\
(0.000)\end{array}$ & $\begin{array}{c}0.039 \\
(0.104)\end{array}$ & $\begin{array}{l}-0.047^{*} \\
(0.056)\end{array}$ & $\begin{array}{l}0.063^{* *} \\
(0.012)\end{array}$ & $\begin{array}{c}0.098^{* * * *} \\
(0.000)\end{array}$ & $\begin{array}{c}0.029 \\
(0.206)\end{array}$ & 0.110 & 1.983 \\
\hline CSRDT & $\begin{array}{c}-1.001^{* * *} \\
(0.000)\end{array}$ & $\begin{array}{l}-0.026 \\
(0.229)\end{array}$ & $\begin{array}{l}-0.007 \\
(0.738)\end{array}$ & $\begin{array}{c}0.373^{* * * *} \\
(0.000)\end{array}$ & $\begin{array}{c}0.062^{* * * *} \\
(0.005)\end{array}$ & $\begin{array}{c}-0.102^{* * * *} \\
(0.000)\end{array}$ & $\begin{array}{l}0.059^{* * *} \\
(0.011)\end{array}$ & $\begin{array}{l}0.110^{* * * *} \\
(0.000)\end{array}$ & $\begin{array}{l}-0.014 \\
(0.502)\end{array}$ & 0.232 & 1.888 \\
\hline
\end{tabular}

Notes: (1) Dependent variables. The first 4 letters of different dependent variables CSRD = corporate social responsibility disclosure. CSRDT is a total score index. The last 2 letters of other variables represent different aspects of information disclosure: $\mathrm{SH}=$ shareholders, $\mathrm{EM}=$ employees, $\mathrm{CS}=\mathrm{consumer}$ services, $\mathrm{EN}=\mathrm{environment}$, $\mathrm{CM}=\mathrm{community}$, OT $=$ other social responsibilities. (2) Explanatory variables. ENVI $=$ environmentally sensitive industry, CONS $=$ consumer sensitive industry, SIZE $=$ firm size, MED $=$ media exposure, $\mathrm{AGE}=$ firm age, $\mathrm{CONC}=$ ownership concentration, INS $=$ ownership by institutional investors, YEAR $=$ time dummy. (3) D-W = Durbin-Watson statistics. Figures in parentheses represent the p-values. (4) ***,*** Significant at $10 \%, 5 \%, 1 \%$ respectively (2-tailed). 
Specifically, environmental sensitive industry, represented by ENVI, is significantly and positively related to the level of CSRD relating to the disclosure of environmental information (CSRDEN), but negatively related to the information disclosure level on employees (CSRDEM) and community (CSRDCM) issues. It has little effect on other CSR information items. Hypothesis 1a is partly supported. However, Consumer sensitivity industry, represented by CONS, is found to have insignificant effect on the CSRD level in all aspects. The results, therefore, reject the hypothesis $1 b$.

In light of the control variables, ownership concentration is positively related to the CSRD in most model specifications. The institutional shareholding is positively related to CSRD in all models consistently. The higher ownership concentration and institutional shareholding percentage is, the higher CSR information disclosure level. YEAR represents the trend that CSR disclosure changes over the sample years. Results indicate that CSR information disclosed in 2009 is less than that in 2008 in general, particularly for CSR information related to environment (CSRDEN) and consumer (CSRDCM), which are significant at the level of 5\%.

Firm age is negatively correlated with the level of CSRD, in contrast to existing studies but it is not surprising in the context of China. Roberts (1992) suggests that firm age is significantly related to environmental disclosure and finds a positive relationship between them. There are several other arguments offering plausible explanations why younger firms are less likely to report social information than older ones. For instance, younger firms are generally smaller and have fewer issues to report than older ones. Considering the possible detriment to their competitiveness, younger firms may be more reluctant to disclose information as they may be price-sensitive (Parsa and Kouhy 2008).

However, younger firms provide a different picture in this study, because firm age in this study refers to the time span between when a firm was listed on SSE and the sample year. As a matter of fact, a lot of newly listed Chinese firms may have existed for a long time before they were listed on SSE. There are three main sources. One source is that some large state-owned enterprises formally listed on the Hong Kong Exchange first, such as Bank of China and Petro China, and then returned to be listed on the Shanghai Stock Exchange. The second source is that some gigantic state-owned enterprises only made their initial public offerings (IPOs) in recent years, including the Industrial and Commercial Bank of China (ICBC), China Life, China Construction Bank and China Mobile. These firms may have existed for a long time but they are considered to be young in terms of their short history in the stock market. The third source is that many Chinese firms have been merged or reorganized in recent years. For example, Handan Steel Co., Chengde Fantai Co. and Tang Steel Co. have been merged to form the new Hebei Steel Group.

The common feature of these firms is that they are considered to be new in the stock market although they have a long operation and public visibility history. They are actually well established in the market and are not afraid of disclosing social information for losing their competitiveness (Qwusu-Ansah, 1998). More importantly, a number of these "newly" listed firms are large state-owned enterprises which are more likely to publish CSR reports than their private counterparts.

\section{CONCLUSIONS AND IMPLICATIONS}

Corporate social information in annual reports represents one of the most important mechanisms that firms can use to influence public policy without being widely scrutinized by ordinary people who do not have easy access to these reports. By analysing the annual reports in 2008 and/or in 2009 published by A-share listed firms on SSE, this paper investigates the determinants of CSR disclosure in emerging China. Our main findings are as follows. First, CSR disclosure has become common practice among Chinese listed firms, but is still very low. Second, firm size, ownership concentration, institutional shareholding and media exposure are positively and significantly associated with the levels of various CSRD indicators. In other words, larger firms, firms with one single controlling owner or institution, and firms willing to share their CSR practice with the public tend to disclose more CSR information. Third, with regard to the industry-specific variables, we find that firms in environmental sensitivity industries disclose more CSR information related the environment improvement, while firms in consumer sensitivity industries do not provide more CSR information related to consumer and community.

Our results provide important policy implications. Firstly, government is the main driver of the development of CSR disclosure. Chinese listed firms are more willing to disclose their CSR information if the government imposes stronger rules and regulations. Over 95\% of firms requested to report CSR information by SSE complied with the regulations. Among those firms reporting CSR information in annual report, only one-third of them voluntarily 
disclose such information without official requirement over the sample period. Hence, facing increasingly serious environment pollution and social conflicts, it is necessary for government to regulate CSR activities and information disclosure to develop a more harmonious society.

Secondly, although both political cost theory and legitimacy theory are important perspectives to understand CSR disclosure practice, political cost appears to be the main constraint for Chinese firms to determine whether to disclose CSR Reports and what to be disclosed in annual reports. The number of firms disclosing CSR reports decreased significantly in 2009. An explanation for this is the absence of detailed mandatory guideline and punishment mechanism for non-compliance. Indeed, two industry-specific proxies also provide evidence on this. For example, firms in high-profile environmentally sensitive industries provide more CSR information related to the environment responsibility, while firms in high-profile consumer proximity industries do not provide more CSR information as expected, the main reason is that environmental regulation and policies are becoming more stringent than others. There are important implications for academics and government regulators. For academics, political cost theory is suitable to understand CSRD in Chinese context. For government regulators, a detailed mandatory guideline on CSR information disclosure is necessary for the effectiveness of mandatory CSR disclosure requirement.

Thirdly, small businesses exploit the annual reports as a strategy to legitimize their corporate social conduct, and ultimately legitimize themselves in the market. In China, it is difficult for small firms to raise finance, which becomes more serious when banks tighten the criteria for granting loans. Then managers of small firms can increase media exposure to build up their corporate image and legitimize their corporate social conduct. Managers of small firms can employ annual reports as an exposure strategy to legitimize their corporate social conduct.

However, our results should be interpreted with certain caveats. First, an unavoidable limitation for the content analysis is rooted. During the process of indexing for each CSR item, it was weighted equally without considering that different items might have different impact on users' decision making. Although this is a little subjective, it is a generally accepted method in most CSR literature (e.g., Branco and Rodrigues, 2008). Second, we do not include the owner identity in variables. As a matter of fact, government controlled firms account for the majority of Chinese listed firms. Whether there is different response to the government regulation between government controlled firms and private firms is unclear. It might have interactive effects on our test for political cost and legitimacy theory, and hence we do not include it in this paper and would make it for our future research.

\section{ACKNOWLEDGEMENT}

Jianling Wang gratefully acknowledges the financial support from Natural Science Foundation Committee of China (Project number: 71202077).

\section{AUTHOR INFORMATION}

Jianling Wang, Ph.D., is assistant professor in the School of Management at Xi'an Jiaotong University. Her main research interests include CSR information disclosure and financial reporting. E-mail: wangil@mail.xjtu.edu.cn

Lin Song, Ph.D., is professor of economics in the School of Economics and Finance at Xi'an Jiaotong University. His main research interests include corporate governance. E-mail: songlin9023@mail.xjtu.edu.cn (Corresponding author)

Shujie Yao, Ph.D., is professor of economics in the School of Contemporary Chinese Studies at University of Nottingham and special chair professor of Xi'an Jiaotong University. His main research interests include Chinese sustainability economics and corporate governance. E-mail: shujie.yao@ nottingham.ac.uk

\section{REFERENCES}

1. Adams, C. A., Hill, W-Y. \& Roberts, C. B. (1998). Corporate Social Reporting Practices in Western Europe: Legitimating Corporate Behaviour. The British Accounting Review, 30(1): 1-21.

2. Ahmed, K. \& Courtis, J.K. (1999). Associations between Corporate Characteristics and Disclosure Levels in Annual Reports: A Meta-analysis. The British Accounting Review, 31(1): 35-61. 
3. Bansal, P. (2005). Evolving Sustainability: A Longitudinal Study of Corporate Sustainable Development. Strategic Management Journal, 26(3): 197-218.

4. Barakas, D. G. \& Brown, A. M. (2008). Corporate Social Reporting and Board Representation: Evidence from Kenyan Banking Sector. Journal of Management and Governance, 12(4): 309-324.

5. Barnett, M. L. (2007). Stakeholder Influence Capacity and the Variability of Financial Returns to Corporate Social Responsibility. Academy of Management Review, 32(3): 794-816.

6. Bewley, K. \& Li, Y. (2000). Disclosure of Environmental Information by Canadian Manufacturing Firms: A Voluntary Disclosure Perspective. Advances in Environmental Accounting and Management, 1: 201-226.

7. Blacconiere, W. G. \& Northcut, W. D. (1997). Environmental Information and Market Reactions to Environmental Legislation. Journal of Accounting, Auditing \& Finance, 12(2): 149-178.

8. Bowman, E. H. \& Haire, M. (1975). A Strategic Posture toward Corporate Social Responsibility. California Management Review, 18(2): 49-58.

9. Brammer, S. \& Pavelin, S. (2008). Factors Influencing the Quality of Corporate Environmental Disclosure. Business Strategy and the Environment, 17(2): 120-136.

10. Branco, M.C. \& Rodrigues, L. L. (2008). Factors Influencing Social Responsibility Disclosure by Portuguese Firms. Journal of Business Ethics, 83(4): 685-701.

11. Brown, N. \& Deegan, C. (1998). The Public Disclosure of Environmental Performance Information - a Dual test of Media Agenda Setting Theory and Legitimacy Theory. Accounting and Business Research, 29(1): 21-41.

12. Cowen, S. S., Ferreri, L. B. \& Parker, L. D. (1987). The Impact of Corporate Characteristics on Social responsibility Disclosure: A Typology and Frequency-based Analysis. Accounting, Organizations and Society, 12(2): 111-122.

13. China Internet Network Information Center (CNNIC). (2013). Statistical Report on Internet Development in China. Retrieved from: http://www1.cnnic.cn

14. Deegan, C., Rankin, M. \& Voght, P. (2000). Firms’ Disclosure Reactions to Major Social Incidents: Australian Evidence. Accounting Forum, 24(1): 101-130.

15. Dierkes, M. \& Preston, L. E. (1977). Corporate Social Accounting Reporting for the Physical Environment: A Critical Review and Implementation Proposal. Accounting, Organizations and Society, 2(1): 3-22.

16. Dowling, J. and Pfeffer, J. (1975). Organizational Legitimacy: Social Values and Organizational behavior. Pacific Sociological Review, 18(1): 122-126.

17. Gao, Y. (2009). Corporate Social Performance in China: Evidence from Large Firms. Journal of Business Ethics, 89(1): 23-35.

18. Gray, R., Kouhy, R. \& Lavers, S. (1995). Corporate Social and Environmental Reporting: A Review of the Literature and a Longitudinal Study of UK Disclosure. Accounting, Auditing and Accountability Journal, 8(2): 47-77.

19. Ghazali, Nazli A. Mohd, (2007). Ownership Structure and Corporate Social responsibility Disclosure: Some Malaysian Evidence. Corporate Governance, 7(3): 251-266.

20. Guthrie, J. \& Parker, L.D. (1989). Corporate Social Disclosure: A Rebuttal of Legitimacy Theory. Accounting and Business Research, 19(76): 343-352.

21. Hasseldine, J., Salama, A. I. \& Toms, J. S. (2005). Quantity Versus Quality: The Impact of Environmental Disclosures on the Reputations of UK PLCS. The British Accounting Review, 37(2): 231-248.

22. Hooghiemstra, R. (2000). Corporate Communication and Impression Management - New Perspectives Why Firms Engage in Corporate Social Reporting. Journal of Business Ethics, 27(1/2): 55-68.

23. Jo, H. \& Kim, Y. (2008). Ethics and Disclosure: A Study of the Financial Performance of Firms in the Seasoned Equity Offerings Market. Journal of Business Ethics, 80(4): 855-878.

24. Mackey, A., Mackey, T. B. \& Barney, J. B. (2007). Corporate Social Responsibility and Firm Performance: Investor Preference and Corporate Strategies. Academy of Management Journal, 32(3): 817-835.

25. Ness, K. E. \& Mirza, A. M. (1991). Corporate Social Disclosure: A Note on the Test of Agency Theory. The British Accounting Review, 23(3): 211-217.

26. Neu, D., Warsame, H. \& Pedwell, K. (1998). Managing Public Impressions: Environmental Disclosures in Annual Reports. Accounting, Organizations and Society, 23(3): 265-282.

27. O'Donovan, G. (2000). Legitimacy Theory as an Explanation for Corporate Environmental Disclosures. Victoria University of Technology, Melbourne: Australia.

28. Orlitzky, M., Schmidt, F. L. \& Rynes S. L. (2003). Corporate Social and Financial Performance: A Meta-analysis. Organization Studies, 24(3): 403-441. 
29. Owusu-Ansah, S. (1998). The Impact of Corporate Attributes on the Extent of Mandatory Disclosure and Reporting by Listed Firms in Zimbabwe. The International Journal of Accounting, 33(5): 605-631.

30. Parsa, S. \& Kouhy, R. (2008). Social Reporting by Firms Listed on the Alternative Investment Market. Journal of Business Ethics, 79(3): 345-360.

31. Patten, D. M. (1991). Exposure, Legitimacy, and Social Disclosure. Journal of Accounting and Public Policy, 10(4): 297-308.

32. Patten, D. M. (1992). Intra-industry Environmental Disclosures in Response to the Alaskan Oil Spill: A Note on Legitimacy Theory. Accounting, Organization and Society, 17(5): 471-475.

33. Patten, D. M. (2002). Media Exposure, Public Policy Pressure, and Environmental Disclosure: An Examination of the Impact of Tri Data Availability. Accounting Forum, 26(2): 152-171.

34. Pava, M.L. \& Krausz, J. (1996). The Association between Corporate Social Responsibility and Financial Performance: The Paradox of Social Cost. Journal of Business Ethics, 15(1): 321-357.

35. Reverte, C. (2009). Determinants of Corporate Social Responsibility Disclosure Ratings by Spanish Listed Firms. Journal of Business Ethics, 88(2): 351-366.

36. Roberts, R. W. (1992). Determinants of Corporate Social Responsibility Disclosure: An Application of Stakeholder Theory. Accounting, Organizations and Society, 17(6): 595-612.

37. Shocker, A.D. \& Sethi, S.P. (1974). An Approach to Incorporating Social Preferences in Developing Corporate Action Strategies. In the Unstable Ground: Corporate Social Policy in a Dynamic Society (Los Angeles: Melville Publishing Company, 67-80.

38. Simon, F.L. (1992). Marketing Green Products in the Triad. Columbia Journal of World Business, 27(3-4): 268-285.

39. Toms, J.S. (2002). Company Resources, Quality Signals and the Determinants of Corporate Environmental Reputation: Some UK Evidence. The British Accounting Review, 34(3): 257-282.

40. Trotman, K. T. \& Bradley, G. W. 1981. Association between Social Responsibility Disclosure and Characteristics of Firms. Accounting, Organizations and Society, 6(4): 355-362.

41. Tsoi, J. (2010). Stakeholders' Perceptions and Future Scenarios to Improve Corporate Social Responsibility in Hong Kong and Mainland China. Journal of Business Ethics, 91(3): 391-404.

42. Ullmann, A. A. (1985). Data in Search of a Theory: A Critical Examination of the Relationships among Social Performance, Social Disclosure, and Economic Performance of U.S. Firms. Academy of Management Review, 10(3): 540-558.

43. Watts, R. L. \& Zimmerman, J. L. (1978). Towards a Positive Theory of the Determination of Accounting Standards. The Accounting Review, 53(1): 112-134.

44. Walden, W. D. \& Schwartz, B. N. (1997). Environmental Disclosures and Public Policy Pressures. Journal of Accounting and Public Policy, 16(2): 125-154.

45. Woodward, D. J., Edwards, P. \& Birkin, F. (1996). Organizational legitimacy and Stakeholder Information Provision. British Journal of Management, 7(4): 329-347. 


\section{NOTES}

